논 문 20-10-10

\title{
$\mathrm{P}$ 형 반전층을 갖는 $\mathrm{ZnO}$ 자외선 수광소자의 제작과 $\mathrm{V}_{\mathrm{r}}-\mathrm{I}_{\mathrm{ph}}$ 특성 분석
}

\section{The Fabrication of ZnO UV Photodetector with p-type Inversion Layer and Analysis of $\mathrm{V}_{\mathrm{r}}-\mathrm{I}_{\mathrm{ph}}$ Properties}

\author{
오상현 ${ }^{1}$, 김덕 규 ${ }^{2}$, 박춘배 ${ }^{1, a}$ \\ (Sang-Hyun Oh', Deok-Kyu Kim², and Choon-Bae Park ${ }^{1, a}$ )
}

\begin{abstract}
Investigation of improving the properties of UV detector which uses the wide bandgap of $\mathrm{ZnO}$ are under active progress. The present study focused on the design and fabrication of $\mathrm{i}-\mathrm{ZnO} / \mathrm{p}$-inversion layer $/ \mathrm{n}^{-} \mathrm{Si}$ Epi. which is characterized with very thin $\mathrm{p}$-type inversion layer for UV detectors. The $\mathrm{i}-\mathrm{ZnO}$ thin film for achieving $\mathrm{p}$-inversion layer which was grown by $\mathrm{RF}$ sputtering at $450{ }^{\circ} \mathrm{C}$ and then annealed at $400{ }^{\circ} \mathrm{C}$ in $\mathrm{O}_{2}$ gas for 20 min shows good intrinsic properties. High (0002) peak intensity of the $\mathrm{i}-\mathrm{ZnO}$ film is shown on XRD spectrum and it is confirmed by XPS analysis that the ratio of $\mathrm{Zn}$ : $\mathrm{O}$ of the $\mathrm{i}-\mathrm{ZnO}$ film is nearly $1: 1$. Measurement shows high transmission of $79.5 \%$ in UV range $(<400 \mathrm{~nm})$ for the $\mathrm{i}-\mathrm{ZnO}$ film. Measurement of $\mathrm{V}_{\mathrm{r}}-\mathrm{I}_{\mathrm{ph}}$ shows high UV photo-current of $1.2 \mathrm{~mA}$ under the reverse bias of $30 \mathrm{~V}$.
\end{abstract}

Key Words : UV detector, p-type inversion layer, ZnO thin films, RF sputtering system

\section{1. 서 론}

상온에서 $3.37 \mathrm{eV}$ 의 직접천이 wide bandgap을 가지고 있는 $\Pi-\mathrm{VI}$ 족 화합물반도체 $\mathrm{ZnO}$ 는 현재 매우 다양한 분야에서 응용되고 있는 $\mathrm{II}-\mathrm{V}$ 족 화 합물 반도체 $\mathrm{GaN}$ 보다 exciton binding 에너지가 약 2.5 배 크고, $\mathrm{Zn}-\mathrm{O}$ 의 결합력이 $\mathrm{Ga}-\mathrm{N}$ 결합에 비 해 크기 때문에 융점이 약 $2000{ }^{\circ} \mathrm{C}$ 로 높으며, 이로 인한 기계적.열적 저항력이 높아 소자로서의 신뢰 성을 높일 수 있는 등 여러 가지 장점을 가지고 있다. $\mathrm{ZnO}$ 는 단파장 영역의 $\mathrm{LEDs}$ 등 발광소자 뿐 만 아니라 UV detector 둥 수광소자 분야에서도 주목을 받고 있다. UV detector는 상업용, 의학용,

1. 원광대학교 전기전자및정보공학부

(전북 익산시 신용동 344-2)

2. 청주대학교 전자정보공학ㅂ

a. Corresponding Author: cbpark@wonkwang.ac.kr 접수일자 : 2007. 8. 24

1차 심사 : 2007. 9. 15

심사완료 : 2007. 9. 18
우주항공 통신 및 군사용 등으로 광범위하게 사용 이 가능하며, 광통신에 응용될 경우 그 전송속도는 현재 사용되고 있는 적외선 레이저를 이용한 통신 에 비해 수십 배 이상 종진될 수 있을 것으로 예 상된다[1-3].

현재 사용되고 있는 반도체형 자외선 센서의 재 료로는 $\mathrm{Si}, \mathrm{SiC}, \mathrm{GaAs}$ 둥이 널리 사용되고 있으며 이러한 재료의 에너지 밴드갭 $(\mathrm{Si}: 1.12 \mathrm{eV}, \mathrm{SiC}$ : $2.9 \mathrm{eV}, \mathrm{GaAs}: 1.42 \mathrm{eV}$ )은 상대적으로 작기 때문 에 자외선 뿐만 아니라 가시광이나 적외선 영역에 서도 응답이 나타나며, 극한 환경에서 동작 할 때 잡음이 발생하는 등의 큰 단점을 가지고 있다 $[4,5]$. 또한, $\mathrm{p}-\mathrm{n}$ 접합형 자외선 센서는 $\mathrm{p}$ 층의 두께가 두 꺼워 전자-정공쌍의 결합이 $\mathrm{p} / \mathrm{n}$ 접합면의 깊은 곳 에서 형성됨으로써 자외선과 같이 파장이 짧은 빛 의 도달에 문제가 발생하며 이로 인해 효율이 감 소하는 문제를 갖고 있다. 이러한 문제를 해결하기 위한 방안으로 $\mathrm{ZnO}$ 의 wide bandgap을 이용한 단 파장 영역의 $\mathrm{UV}$ detector에 관한 연구가 현재 활 발히 진행되고 있다[6-10]. 
본 연구에서는 $\mathrm{p}$ 층의 두께를 최소화 할 수 있는 방안으로 $3.37 \mathrm{eV}$ bandgap의 $\mathrm{ZnO}$ 와 $1.12 \mathrm{eV}$ 의 bandgap의 $\mathrm{Si}$ 의 접합부에서 반전층이 발생하는 원 리를 이용하였다. $\mathrm{p}$ 층의 두께가 $1,000 \AA$ 정도로 매 우 얇은 $\mathrm{i}-\mathrm{ZnO} / \mathrm{p}^{-}$반전층 $/ \mathrm{n}^{-} \mathrm{Si}$ Epi.구조의 UV detector를 설계하고 제작하였다. $\mathrm{RF}$ sputtering법 으로 $\mathrm{n}^{-} \mathrm{Si}$ Epi. wafer위에 $\mathrm{i}-\mathrm{ZnO}$ 박막을 증착하 였으며, 증착온도와 열처리 조건에 따론 $\mathrm{Zn}$ 와 $\mathrm{O}$ 의 정량분석을 실시하였다. 제작된 $\mathrm{UV}$ detector의 $\mathrm{V}_{\mathrm{r}}-\mathrm{I}_{\mathrm{ph}}$ 특성을 비교 분석하였다.

\section{2. 실 험}

\section{1 실험 방법}

$\mathrm{p}$ 형 반전층을 갖는 $\mathrm{ZnO}$ 계 $\mathrm{UV}$ detector는 그림 1 의 모식도와 같이 $\mathrm{i}-\mathrm{ZnO} / \mathrm{p}^{-}$반전층 $/ \mathrm{n}^{-}-\mathrm{Si}$ Epi.구조 로 설계-제작하였다. 시편의 제조는 $\mathrm{n}^{-}-\mathrm{Si} \mathrm{Epi}$. (14.5 $17.0 \Omega \cdot \mathrm{cm}$ )wafer위에 $\mathrm{p}$-반전 층의 전극 역할을 하는 $\mathrm{p}^{+}-\mathrm{Si}$ 충을 Ion-implanter장비를 사용 $2 \mathrm{um}$ 두께로 제작하였다. $\mathrm{ZnO}$ 박막 증착 전 native oxide를 제거하기 위해 BHF (Buffered $\mathrm{HF}, \mathrm{HF}$ : D.I water $=7: 1$ )용액에서 5 분간 산화물을 제거 하고 D.I water에서 초음파 세척을 실시하였다. $\mathrm{ZnO}$ 박막은 $\mathrm{RF}$ magnetron sputtering 법으로 $\mathrm{ZnO}$ (99.999\%) 타겟을 이용하여 $150 \mathrm{~nm}$ 두께로 증착 하였다. 증착조건은 초기진공도 $8.0 \times 10^{-6}$ Torr, 작업진공도 $15 \mathrm{mTorr}$ 이었고, $\mathrm{RF}$ power는 $120 \mathrm{~W}$ 로 하였으며, 분위기는 아르곤과 산소를 각각 $40 \mathrm{sccm}$

표

1. $\mathrm{ZnO}$ 박막 증착을 위한 $\mathrm{RF}$ 마그네트론 스퍼터링 조건.

Table 1. Conditions of RF magnetron sputtering to deposit $\mathrm{ZnO}$ thin films.

\begin{tabular}{|c|c|c|}
\hline & 파라미터 & 공정조긴 \\
\hline 증착 & $\begin{array}{l}\text { 기판 } \\
\text { 초기 압력 } \\
\text { 작업 압력 } \\
\mathrm{RF} \text { power } \\
\text { 기판온도 } \\
\text { 증착시간 } \\
\text { 가스비 }\end{array}$ & $\begin{array}{l}\mathrm{n}^{-}-\mathrm{Si} \text { Epi. wafer } \\
8.0 \times 10^{-6} \text { Torr. } \\
15 \mathrm{mTorr} . \\
120 \mathrm{~W} \\
300,450,600{ }^{\circ} \mathrm{C} \\
1 \mathrm{hr} \\
\mathrm{Ar}: \mathrm{O}_{2}=40: 10\end{array}$ \\
\hline $\begin{array}{l}\text { 후열 } \\
\text { 처리 }\end{array}$ & $\begin{array}{l}\text { 분위기 } \\
\text { 온도 } \\
\text { 시간 }\end{array}$ & $\begin{array}{l}\mathrm{O}_{2} \\
400{ }^{\circ} \mathrm{C} \\
20 \mathrm{~min}\end{array}$ \\
\hline
\end{tabular}

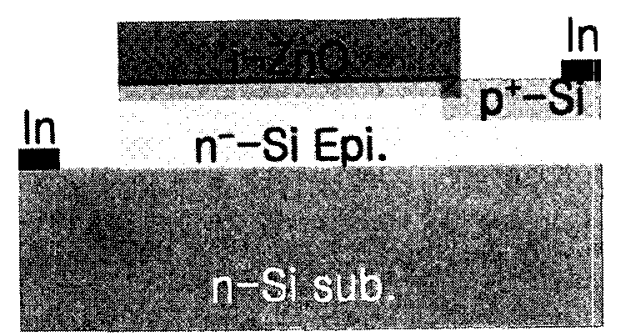

그림 1. $\mathrm{p}$ 형 반전층을 갖는 $\mathrm{ZnO}$ 계 자외선 수광소 자의 모식도.

Fig. 1. Structural drawing of $\mathrm{ZnO}$ based UV photodetector with p-type inversion layer.

과 $10 \mathrm{sccm}$ 으로 혼합 설정하였다. 반전층 형성을 위한 가장 중요한 요소인 $\mathrm{i}-\mathrm{ZnO}$ 를 증착하기위해 중착온도는 $300{ }^{\circ} \mathrm{C}, 450{ }^{\circ} \mathrm{C}, 600{ }^{\circ} \mathrm{C}$ 로 변화를 주었 으며, 분위기 열처리는 선행연구롤 통해 확인한 결 과를 이용해 $400{ }^{\circ} \mathrm{C}$ 에서 20 분 동안 $\mathrm{O}_{2}$ 분위기에서 이루어졌다[11,12]. 이러한 $\mathrm{ZnO}$ 박막의 증착조건을 표 1에 정리하였다. 제작된 소자의 $\mathrm{V}_{\mathrm{r}}-\mathrm{I}_{\mathrm{ph}}$ 특성 분석 을 위해 전극은 In을 $\mathrm{n}-\mathrm{Si}$ sub.와 $\mathrm{p}^{+}-\mathrm{Si}$ 층에 열증 착기를 이용하여 증착하였다.

\section{2 특성 분석}

증착온도를 파라메터로 증착된 $\mathrm{ZnO}$ 박막의 미 세구조와 표면형상을 관찰하기 위해서 $\mathrm{FE}-\mathrm{SEM}$ (Field Emission Scanning Electron Microscope)분 석을 하였다. XRD (X-ray Diffraction)분석을 통해 $\mathrm{ZnO}$ 박막의 결정성을 관찰하였고, 증착된 $\mathrm{ZnO}$ 박 막의 $\mathrm{Zn}$ 와 $\mathrm{O}$ 의 정량분석을 위해 XPS (X-ray Photo-electron Spectrometer, KBSI: ESCALAB 250 XPS spectrometer)를 이용하였다. 또한, 증착된 박막의 빛 투과율을 알아보기 위해 $300 \mathrm{~nm} \sim 700$ $\mathrm{nm}$ 파장에 걸쳐 투과도를 측정하였다. 제작된 소자의 $\mathrm{V}_{\mathrm{r}}-\mathrm{I}_{\mathrm{ph}}$ 특성의 변화를 확인하기 위해 Semiconductor Parameter Analyser (HP 4155A)를 사용하였고, 자외선 광원으로는 peak 파장 $352 \mathrm{~nm} \sim 368 \mathrm{~nm}$, 출력 $1.5 \mathrm{~W}$ 의 $\mathrm{Hg} \mathrm{Lamp}$ 를 사용하였다.

\section{3. 실험결과 및 고찰}

\section{1 구조적 특성 분석}

그림 2는 온도에 따라 증착된 $\mathrm{ZnO}$ 박막의 표면을 $\mathrm{FE}-\mathrm{SEM}$ 으로 분석한 것이다. 모든 $\mathrm{ZnO}$ 박막에서 mirror-like하고 평탄한 표면을 얻었다. 증착된 $\mathrm{ZnO}$ 

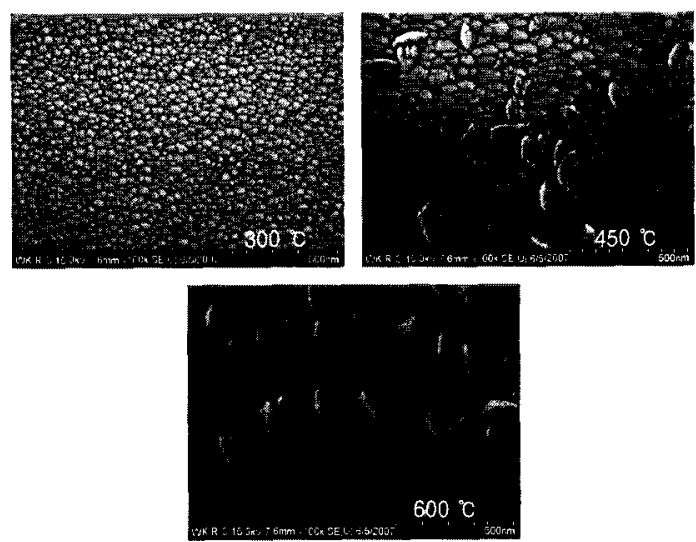

그림 2. 증착온도에 따른 $\mathrm{ZnO}$ 박막의 $\mathrm{FE}-\mathrm{SEM}$ 사진.

Fig. 2. FE-SEM photographs of $\mathrm{ZnO}$ fhin films with deposition temperature.

박막은 증착온도에 따라 두 가지 형태를 보이고 있다. $300{ }^{\circ} \mathrm{C}$ 에서 증착된 $\mathrm{ZnO}$ 박막의 표면은 작은 결정립들이 전 영역에 걸쳐 균일하게 존재해 있음 을 확인하였으며, $450{ }^{\circ} \mathrm{C}, 600{ }^{\circ} \mathrm{C}$ 에서 중착된 박막 은 길쭉한 형태의 큰 결정립과 작은 결정립이 공 존함을 확인 할 수 있었다. 증착온도가 증가하면서 결정의 치밀화가 발생하여 결정립이 커진 것으로 판단된다. 또한, 박막의 단면 관찰을 통해 관찰된 박막의 두께는 모든 증착온도에서 약 $150 \mathrm{~nm}$ 임을 확인하였다.

그림 3 은 증착온도에 따라 증착된 $\mathrm{ZnO}$ 박막의 $\mathrm{XRD}$ 패턴을 보여주고 있다. 모든 $\mathrm{ZnO}$ 박막에서 $\mathrm{ZnO}(0002)$ 면과 관계된 피크가 야 $34.4^{\circ}$ 에서 관찰 되었으며 증착 온도에 관계없이 $\mathrm{c}$-축 우선 배향성 을 보였다. $\mathrm{ZnO}(0002)$ 피크의 intensity는 증착 온 도가 증가하면서 강해지다가 다시 약해지는 패턴 을 보이고 있다. 즉, $450{ }^{\circ} \mathrm{C}$ 에서 증착된 $\mathrm{ZnO}$ 박막 에서 가장 강한 intensity를 나타내었고, $600{ }^{\circ} \mathrm{C}$ 에 서 가장 약한 intensity를 나타내었다. 또한, $\mathrm{ZnO}$ (0002)푀크의 FWHM (Full Width at Half Maximum)은 증착 온도가 $450{ }^{\circ} \mathrm{C}$ 보다 높아지면 증가하는 경향을 나타내었다. $300{ }^{\circ} \mathrm{C}, 450{ }^{\circ} \mathrm{C}, 600$ ${ }^{\circ} \mathrm{C}$ 에서의 $\mathrm{FWHM}$ 은 각각 $0.7^{\circ}, 0.7^{\circ}, 0.94^{\circ}$ 였다. $450{ }^{\circ} \mathrm{C}$ 에서 증착된 $\mathrm{ZnO}$ 박막에서 강한 intensity와 $0.7^{\circ}$ 로 가장 작은 $\mathrm{FWHM}$ 을 나타내고 있다. 삽입 그림은 $\mathrm{SiO}_{2}$ (0002)면과 관계된 피크를 나타낸 것 으로 약 $62.8^{\circ}$ 에서 관찰되었으며 증착 온도가 증가 하면서 intensity가 증가핢을 알 수 있다. 특히, 600 ${ }^{\circ} \mathrm{C}$ 에서의 $\mathrm{SiO}_{2}$ 피크 intensity는 $450{ }^{\circ} \mathrm{C}$ 경우 보다

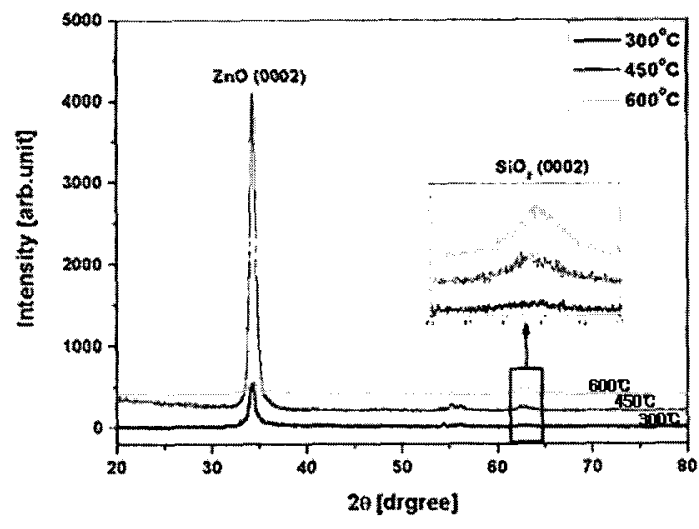

그림 3. 중착 온도에 따른 $\mathrm{ZnO}$ 박막의 $\mathrm{XRD}$ 결과.

Fig. 3. XRD results of $\mathrm{ZnO}$ thin films with various deposition temperature.

두 배정도 강하게 나타났다. $\mathrm{FE}-\mathrm{SEM}$ 결과 $450{ }^{\circ} \mathrm{C}$ 와 $600{ }^{\circ} \mathrm{C}$ 에서 증착된 $\mathrm{ZnO}$ 박막의 미세구조가 비 슷하였지만 XRD결과 결정성에 큰 차이를 보이고 있다. 이 결과는 기판과 $\mathrm{ZnO}$ 계면에 생성된 $\mathrm{SiO}_{2}$ 층에 의한 것으로 판단된다[8]. $\mathrm{FE}-\mathrm{SEM}$ 결과와 $\mathrm{XRD}$ 결과를 볼 때 증착 온도가 $\mathrm{ZnO}$ 박막의 미세 구조와 결정성에 상당한 영향을 주고 있음을 확인 하였다.

증착된 $\mathrm{ZnO}$ 박막의 $\mathrm{Zn}$ 와 $\mathrm{O}$ 의 결합 에너지와 정량비를 분석하기 위해 XPS 분석을 실시하였다. 표 2에 증착온도에 따른 $\mathrm{Zn}$ 와 $\mathrm{O}$ 원소들의 결합 에 너지와 성분비를 정리하였다. 온도에 따른 $\mathrm{Zn}_{2 \mathrm{p}}$ 와 $\mathrm{O}_{1 \mathrm{~s}}$ 의 걸합 에너지를 보면 $300{ }^{\circ} \mathrm{C}, 450{ }^{\circ} \mathrm{C}$ 에서 비 슷하였고, $600{ }^{\circ} \mathrm{C}$ 에서는 다른 온도에 비해 조금 중 가하였다. $300{ }^{\circ} \mathrm{C}, 450{ }^{\circ} \mathrm{C}, 600{ }^{\circ} \mathrm{C}$ 에서 증착된 $\mathrm{ZnO}$ 박막의 $\mathrm{Zn}$ : O성분비는 각각 $1: 1.1315,1$ : $1.0592,1$ : 1.1020 였으며, $450{ }^{\circ} \mathrm{C}$ 에서 증착된 $\mathrm{ZnO}$ 박막에서 $1: 1$ 에 가장 가까움을 확인할 수. 있었다.

표

2. $\mathrm{XPS}$ 분석에서 측정된 $\mathrm{Zn} 2 \mathrm{p}$ 와 $\mathrm{Ols}$ 의 결 합 에 너지와 $\mathrm{Zn} / \mathrm{O}$ 의 비율.

Table 2. Binding energy and $\mathrm{Zn} / \mathrm{O}$ ratio measured at XPS analysis.

\begin{tabular}{|c|c|c|c|c|}
\hline \multirow{2}{*}{ Sub. } & \multicolumn{2}{|c|}{$\mathrm{Zn}_{2 \mathrm{p}}[\mathrm{eV}]$} & \multirow{2}{*}{$\begin{array}{c}\mathrm{O}_{\mathrm{s}} \\
{[\mathrm{eV}]}\end{array}$} & \multirow{2}{*}{$\begin{array}{l}\mathrm{Zn} / \mathrm{O} \\
\text { rate }\end{array}$} \\
\hline & $1 \mathrm{st}$ & $2 \mathrm{st}$ & & \\
\hline $300^{\circ} \mathrm{C}$ & 1022.4 & 1045.5 & 531.15 & $1 / 1.315$ \\
\hline $450^{\circ} \mathrm{C}$ & 1022.35 & 1045.45 & 531.1 & $1 / 1.0592$ \\
\hline $600{ }^{\circ} \mathrm{C}$ & 1022.5 & 1045.7 & 531.3 & $1 / 1.1020$ \\
\hline
\end{tabular}




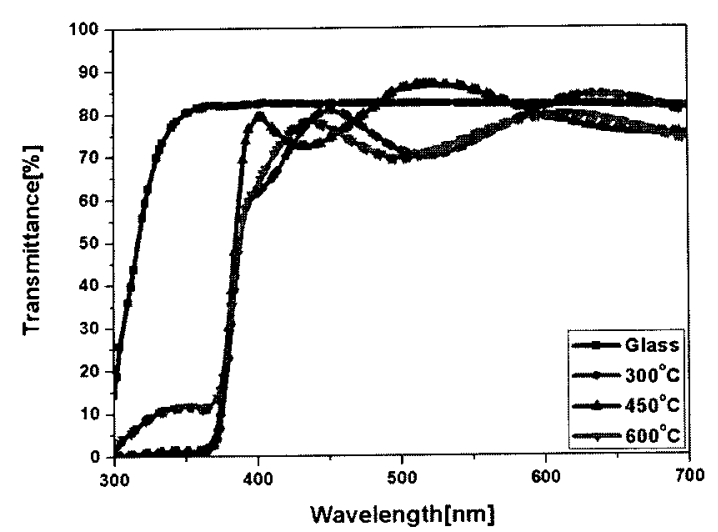

그림 4. 증착온도에 따른 $\mathrm{ZnO}$ 박막의 투과도.

Fig. 4. Transmittance of $\mathrm{ZnO}$ films with various deposition temperature.

그림 4는 증착 온도에 따른 $\mathrm{ZnO}$ 박막의 300 $\mathrm{nm}$ $700 \mathrm{~nm}$ 파장에서의 투과도이다. 투과도를 측정하기 위해 유리기판 위에 $\mathrm{ZnO}$ 박막을 성장하 고 측정하였다. 유리 기판은 $360 \mathrm{~nm}$ 에서 $700 \mathrm{~nm}$ 까지 파장에서 $82 \%$ 의 투과율을 보인 반면 $\mathrm{ZnO}$ 박막은 $400 \mathrm{~nm}$ 에서 $700 \mathrm{~nm}$ 범위의 파장에서 파장 에 따라 $70 \%$ $87 \%$ 의 투과율이 변화하였다. 특히, $\mathrm{ZnO}$ 박막들은 $\mathrm{ZnO}$ 밴드갑 파장 $(370 \mathrm{~nm}$, - $3.34 \mathrm{eV}$ )이후에 급격히 증가하는 특성을 보이고 있다. $450{ }^{\circ} \mathrm{C}$ 에서 증착된 $\mathrm{ZnO}$ 박막은 $\mathrm{UV}$ 영역 (< $400 \mathrm{~nm}$ )에서 $79.5 \%$ 의 높은 투과도를 나타낸 반 면 $300{ }^{\circ} \mathrm{C}$ 와 $600{ }^{\circ} \mathrm{C}$ 에서 증착된 $\mathrm{ZnO}$ 박막은 $62 \%$ 의 투과율을 보이고 있다. 이 현상은 XRD결과와 일치하는 것으로 고품질의 $\mathrm{ZnO}$ 박막 성장에 의한 것으로 판단된다.

$\mathrm{p}$ 형 반전총을 이용하기 위해서는 진성 $\mathrm{ZnO}$ 박 막을 성장하는 것이 매우 중요한데 이는 진성 $\mathrm{ZnO}$ 박막과 $\mathrm{n}-\mathrm{Si}$ 을 접합하면 큰 밴드갭 차이에 의해 $\mathrm{p}$ 형 반전층이 형성되기 때문이다. 그림 5 는 진성 $\mathrm{ZnO}$ 박막과 $\mathrm{n}^{-}-\mathrm{Si}$ 층의 접합 후의 에너지밴드 구조를 나타내고 있다. 그림에서와 같이 wide bandgap $\mathrm{ZnO}$ 반도체와 $\mathrm{Si}$ 반도체의 이종 접합에 의한 에너지밴드 접합부에는 돌출형의 $\mathrm{p}$-반전층이 페르미준위 $\mathrm{E}_{\mathrm{f}}$ 위에 형성된다[13]. 일반적으로 $\mathrm{ZnO}$ 박막은 $\mathrm{n}$-type특성을 나타내는데 이 경우 페르미 준위의 상승에 의해 반전층도 사라지게 된다. 그러 므로 진성 $\mathrm{ZnO}$ 박막의 성장은 $\mathrm{UV}$ Detector 제작 의 성공여부를 판단할 수 있는데, 이를 확인하기 위해 Hall측정을 실시하였다. 그 결과는 모든 $\mathrm{ZnO}$ 박막에서 높은 저항 값이 나타나 Hall측정이 불가능

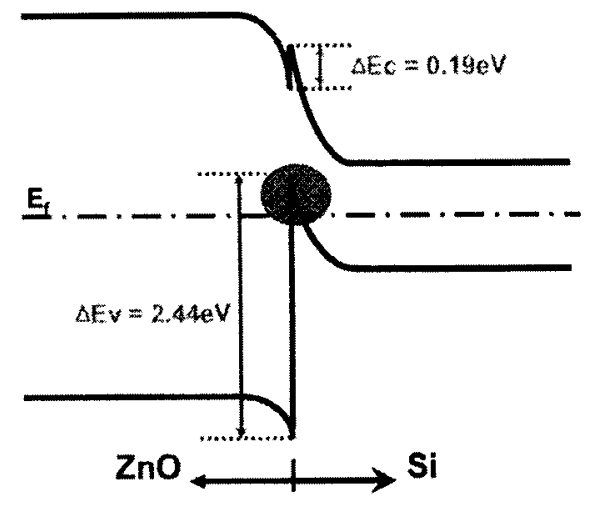

그림 5. 반전층 생성 밴드 다이어그램.

Fig. 5. Band diagram of inversion layer.

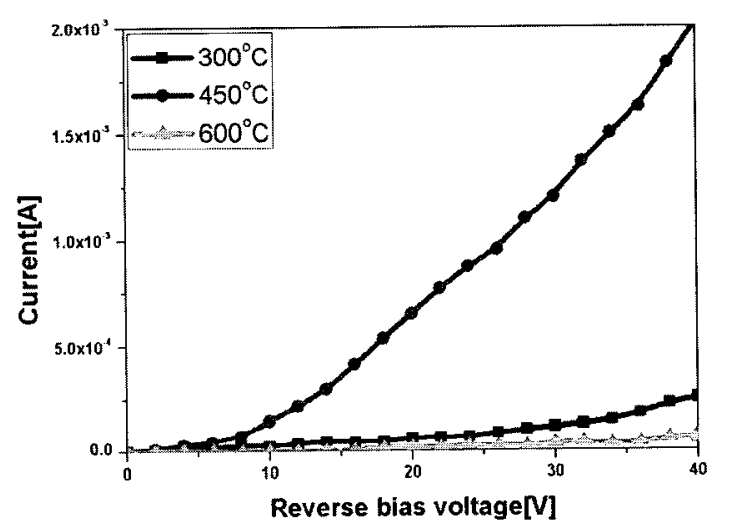

그림 6. 자외선 수광소자의 $\mathrm{V}_{\mathrm{r}}-\mathrm{I}_{\mathrm{ph}}$ 특성.

Fig. 6. The $V_{r}-I_{p h}$ characteristics of $U V$ detectors.

하였다. 이러한 Hall측정 결과와 XPS 분석을 통해 진성 $\mathrm{ZnO}$ 박막이 생성되었음을 확인할 수 있으며, 따라서 $\mathrm{p}$ 형 반전층이 생성된 것으로 판단된다.

그림 6 은 중착 온도에 따라 제작된 소자의 $\mathrm{UV}$ 조사 상태에서의 $\mathrm{V}_{\mathrm{r}}-\mathrm{I}_{\mathrm{ph}}$ 특성을 나타내고 있다. 30 $\mathrm{V}$ reverse bias에서 측정한 광전류는 $450{ }^{\circ} \mathrm{C}$ 에서 증착된 소자에서 $1.2 \mathrm{~mA}$ 로 가장 크게 나타났고, $600{ }^{\circ} \mathrm{C}$ 에서 증착된 소자에서 $0.04 \mathrm{~mA}$ 로 가장 작게 나타났다. 이 현상은 앞선 $\mathrm{XRD}$, 투과도 특성에서 나타난 바와 같이 $450{ }^{\circ} \mathrm{C}$ 에서 고품질의 $\mathrm{ZnO}$ 박막 이 증착되었으며, 이로 인해 많은 양의 UV 빛이 반전층 내로 투과되어 많은 양의 전도 캐리어를 생성하여 나타나는 현상으로 판단된다. UV 영역에 서 비슷한 투과도를 나타냄에도 불구하고 $600{ }^{\circ} \mathrm{C}$ 에서 증착된 소자가 $300{ }^{\circ} \mathrm{C}$ 에서 중착된 소자에 비 
해 $\mathrm{V}_{\mathrm{r}}-\mathrm{I}_{\mathrm{ph}}$ 븍성이 나쁜 이유는 기퐌과 $\mathrm{ZnO}$ 박막 계 면에 생성된 oxide층에 의한 것으로 판단되며, 이 는 $\mathrm{XRD}$ 의 $\mathrm{SiO}_{2}$ 층의 intensity 값과도 일치한다[8].

\section{4. 결 론}

본 연구에서는 $\mathrm{p}$ 형 반전층을 갖는 두께가 매우 얇은 $\mathrm{i}-\mathrm{ZnO} / \mathrm{p}^{-}$반전층 $/ \mathrm{n}^{-}-\mathrm{Si}$ Epi.구조의 $\mathrm{ZnO}$ 자외선 수광소자를 제작하였다. RF magnetron sputtering 법으로 $\mathrm{ZnO}$ 박막을 증착하고, 박막의 미세구조와 전기적·광학적 톡성 그리고 $\mathrm{V}_{\mathrm{r}}-\mathrm{I}_{\mathrm{ph}}$ 특성을 분석하였 다. $\mathrm{p}$-반전층 형성을 위한 가장 중요한 요소기술은 $\mathrm{i}-\mathrm{ZnO}$ 박막을 형성하는데있다. $\mathrm{i}-\mathrm{ZnO}$ 박막을 증착 하기위해 증착온도는 $300{ }^{\circ} \mathrm{C}, 450{ }^{\circ} \mathrm{C}, 600{ }^{\circ} \mathrm{C}$ 로 변 화를 주었으며, 분위기 얼처리는 선행연구 결과를 적용해 $400{ }^{\circ} \mathrm{C}$ 에서 20 분 동안 $\mathrm{O}_{2}$ 분위기에서 이루 어졌다. 제작된 소자의 특성을 분석한 결과를 정리 하면 다음과 같다.

1) $\mathrm{FE}-\mathrm{SEM}$ 분석을 통해 모든 $\mathrm{ZnO}$ 박막에서 Mirror-like하고 평탄한 표면을 확인하였고, 두깨는 약 $150 \mathrm{~nm}$ 임을 확인하였다.

2) $\mathrm{XRD}$ 패턴분석을 통해 중착 온도에 관계없이 모든 $\mathrm{ZnO}$ 박막에서 $\mathrm{c}$-축 우선 배향성을 보 였으며, $450{ }^{\circ} \mathrm{C}$ 에서 증착된 $\mathrm{ZnO}$ 박막에서 가 장 강한 intensity를 나타냈다. 또한, $\mathrm{ZnO}$ (0002) 피크의 FWHM은 증착온도가 증가하 면서 각각 $0.7^{\circ}, 0.7^{\circ}, 0.94^{\circ}$ 로 증가하였다. 또한, 약 $62.8^{\circ}$ 에서 $\mathrm{SiO}_{2}$ (0002)면과 관계된 피크가 관찰되었으며, 증착 온도가 증가 하면 서 intensity가 증가였다.

3) XPS 분석을 통해 $450{ }^{\circ} \mathrm{C}$ 에서 증착된 $\mathrm{ZnO}$ 박막의 $\mathrm{Zn}$ 와 $\mathrm{O}$ 의 비율이 $1: 1.0592$ 로 $\mathrm{i}-\mathrm{ZnO}$ 박막에 가장 근접함을 확인하였다. Hall측정 에서도 절연체임을 확인 할 수 있었다.

4) 투과도 분석을 통해 $\mathrm{ZnO}$ 박막들은 $\mathrm{ZnO}$ 밴드 갭 파장 $(370 \mathrm{~nm},-3.34 \mathrm{eV})$ 이후에 급격히 증가하는 특성을 보이고 있다. $450{ }^{\circ} \mathrm{C}$ 에서 증 착된 $\mathrm{ZnO}$ 박막은 $\mathrm{UV}$ 영역 $(<400 \mathrm{~nm})$ 에서 $79.5 \%$ 의 높은 투과도를 나타낸 반면 $300{ }^{\circ} \mathrm{C}$ 와 $600{ }^{\circ} \mathrm{C}$ 에서 증착된 $\mathrm{ZnO}$ 박막은 $62 \%$ 의 투과율을 보이고 있음을 알 수 있었다.

5) $30 \mathrm{~V}$ reverse bias에서 측정한 UV 광전류 특성도 $450{ }^{\circ} \mathrm{C}$ 에서 $\mathrm{ZnO}$ 박막이 증착된 소자 에서 $1.2 \mathrm{~mA}$ 로 가장 우수한 $\mathrm{V}_{\mathrm{r}}-\mathrm{I}_{\mathrm{ph}}$ 특성을 나타냈다.
이상의 연구결과를 통해 고품질의 $\mathrm{i}-\mathrm{ZnO}$ 박막 을 제작할 수 있을 뿐만 아니라, $\mathrm{ZnO}$ 박막을 이용 한 UV detector의 실용 가능성을 확인하였다.

\section{감사의 글}

본 연구는 중소기업청에서 지원하는 산학연협력 기업부설연구소설치지원사업의 연구결과로 수행되 었음.

\section{참고 문헌}

[1] Y. R. Ryu, T. S. Lee, J. A. Lubguban, H. W. White, Y. S. Park, and C. J. Youn, "ZnO devices: Photodiodes and p-type field-effect transistors", Appl. Phys. Lett., Vol. 87, p. 153504. 2005.

[2] 이주영, 김홍승, 이정윤, 장지호, 안형수, 양민, 이삼녕, " $\mathrm{Si}$ 기판 위에 증착된 $\mathrm{ZnO}$ 막의 열처 리 효과에 대한 구조적, 광학적 특성”, 한국물 리학회, 48권, 5호, p. 458, 2004.

[3] C. H. Park, I. S. Jeong, H. S. Bae, T. G. $\mathrm{Kim}$, and S. Im, "n-ZnO/p-Si photodiodes fully isolated by $\mathrm{B}^{+}$ion-implantation", Nucleare Instruments and Methods in Physics Research B, Vol. 216, p. 127, 2004.

[4] M. A. Khan, Q. Chen, J. Sun, M. Shur, and B. Gelmont, "Two-dimensional electron gas in GaN/AlGaN heterostructures deposited using trimethylamine-alane as the aluminum source in low pressure metalorganic chemical vapor deposition", Appl. Phys. Lett., Vol. 67, p. $1429,1995$.

[5] S. N. Mohammad, A. A. Salvador, and H. Morkoc, "Emerging gallium nitride based devices", Proceeding of the IEEE, Vol. 83, No. 10, p. 1306, 1995.

[6] C. H. Park, J. Y. Lee, S. Im, and T. G. $\mathrm{Kim}, \quad " \mathrm{n}-\mathrm{ZnO} / \mathrm{p}-\mathrm{Si}$ photodiodes fabricated using ion-beam induced isolation technique", Nuclear Instruments and Methods in Physics Research B, Vol. 206, p. 432, 2003.

[7] T.-H. Moon, M.-C. Jeong, W. Lee, and J.-M. Myoung, "Schottky metal library for $\mathrm{ZnO}$-Based UV photodiode fabricated by the combinatorial ion beam-assisted deposition", Applied Surface Science, Vol. 240, p. 280, 2005. 
[8] J. Y. Lee, Y. S. Choi, W. H. Choi, H. W. Yeom, Y. K. Yoon, J. H. Kim, and S. Im, "Characterization of films and intyerfaces in n-ZnO/p-Si photodiodes", Thin Solid Films, Vol. 420-421, p. 112, 2002.

[9] Y. W. Heo, B. S. Kang, L. C. Tien, D. P. Norton, F. Ren, J. R. La Toche, and S. J. Pearton, "UV photoresponse of single $\mathrm{ZnO}$ nanowires", Appl. Phys. A, Vol. 80, p. 497, 2005.

[10] F. Masuoka, K. Ooba, H. Sasaki, H. Endo, S. Chiba, K. Maeda, H. Yoneyama, I. Niikura, and Y. Kashiwaba, "Applicability of $\mathrm{ZnO}$ single crystals for ultraviolet sensors", Phus. Sat. Sol. (c), Vol. 3, No. 4, p. 1238, 2006.
[11] 유인성, 소순진, 박춘배, “기판의 결정구조에 따른 $\mathrm{RF}$ 스펴터링 $\mathrm{ZnO}$ 박막의 성장과 미세 구조 분석", 전기전자재료학회논문지, 19 권, 5 호, p. 461, 2006.

[12] 왕민성, 유인성, 박춘배, "In-situ 분위기 Annealing에 따른 $\mathrm{ZnO} /$ Sapphire(0001) 박막 의 구조적 특성 분석”, 전기전자재료학회논문 지, 19권, 8호, p. 769, 2006.

[13] H.-S. Kwack, Y.-H. Cho, G. H. Kim, M. R. Park, D. H. Youn, S. B. Bae, K. S. Lee, J.-H. Lee, J.-H. Lee, T. W. Kim, T. W. Kang, and K. L. Wang, "Optical properties and carrier dynamics of two-dimensional electrons in AlGaN/GaN single heterostructures", Appl. Phys. Lett., Vol. 87, p. 041909. 2005. 